\title{
Article
}

\section{Synergistic Effect of Plant Extracts on Endodontic Pathogens Isolated from Teeth with Root Canal Treatment Failure: An In Vitro Study}

\author{
Suraj Arora ${ }^{1, *}$, Shahabe Abullais Saquib ${ }^{2}$, Youssef A Algarni ${ }^{1}$, Mohammed Abdul Kader ${ }^{1}$, Irfan Ahmad ${ }^{3}$, \\ Mohammad Y Alshahrani ${ }^{3}{ }^{1}$, Priyanka Saluja ${ }^{4}$, Suheel Manzoor Baba ${ }^{1}{ }^{(\mathbb{D}}$, Anshad M. Abdulla ${ }^{5}$ and \\ Shashit Shetty Bavabeedu ${ }^{1}$ (I)
}

check for updates

Citation: Arora, S.; Saquib, S.A.; Algarni, Y.A; Kader, M.A.; Ahmad, I.; Alshahrani, M.Y; Saluja, P.; Baba, S.M.; Abdulla, A.M.; Bavabeedu, S.S. Synergistic Effect of Plant Extracts on Endodontic Pathogens Isolated from Teeth with Root Canal Treatment Failure: An In Vitro Study. Antibiotics 2021, 10, 552. https://doi.org/ 10.3390/antibiotics10050552

Academic Editor: William N. Setzer

Received: 13 March 2021

Accepted: 6 May 2021

Published: 9 May 2021

Publisher's Note: MDPI stays neutral with regard to jurisdictional claims in published maps and institutional affiliations.

Copyright: (c) 2021 by the authors. Licensee MDPI, Basel, Switzerland. This article is an open access article distributed under the terms and conditions of the Creative Commons Attribution (CC BY) license (https:/ / creativecommons.org/licenses/by/ $4.0 /)$.
1 Department of Restorative Dental Sciences, College of Dentistry, King Khalid University, Abha 61321, Saudi Arabia; yalgarni@kku.edu.sa (Y.AA.); msaheb@kku.edu.sa (M.A.K.); baba@kku.edu.sa (S.M.B.); sbavabeedu@kku.edu.sa (S.S.B.)

2 Department of Periodontics and Community Dental Sciences, College of Dentistry, King Khalid University, Abha 61321, Saudi Arabia; sshahabe@kku.edu.sa

3 Department of Clinical Laboratory Sciences, College of Applied Medical Sciences, King Khalid University, Abha 61321, Saudi Arabia; imahmood@kku.edu.sa (I.A.); moyahya@kku.edu.sa (M.YA.)

4 Department of Conservative Dentistry and Endodontics, JCD Dental College, Sirsa 125055, India; priyanka.salujaarora@gmail.com

5 Department of Pediatric Dentistry \& Orthodontics, College of Dentistry, King Khalid University, Abha 61321, Saudi Arabia; anshad@kku.edu.sa

* Correspondence: sprakash@kku.edu.sa or surajarorasgrd@yahoo.co.in; Tel.: +966-53-1485844
Abstract: Background and objectives: This study aimed to evaluate the synergistic antimicrobial activity of extracts obtained from Salvadora persica (Miswak), Commiphora molmol (myrrh) and Azadirachta indica (neem) in combination with commercially available antimicrobial agents: penicillin, tetracycline, ofloxacin and fluconazole on endodontic pathogens such as Enterococcus faecalis, Streptococcus mitis, Actinomyces naeslundii and Candida albicans. Materials and Methods: Microbiological samples from the root canals of the teeth undergoing retreatment were taken using sterile paper points kept at full length in the canal for $30 \mathrm{~s}$. The disc diffusion method was used to check the susceptibility of microbes to the plant extracts and antimicrobials by measuring the diameter of the inhibition zones. Against the microbes, minimum inhibitory concentration (MIC) and minimum bactericidal concentration (MBC)/minimum fungicidal concentration (MFC) of the plant extracts were assessed. The fractional inhibitory concentration index (FICI) was used to estimate the synergistic effect of plant extracts combined with antimicrobials against the resistant endodontic microbes. Results: The findings clearly indicate the effectiveness of all the three plant extracts, Commiphora molmol, Azadirachta indica, Salvadora persica, against all the experimental pathogenic microorganisms except for the ineffectiveness of Azadirachta indica, Salvadora persica against Candida albicans. Maximum antimicrobial activity was displayed by Azadirachta indica against Enterococcus faecalis (MIC $=0.09 \pm 1.2 \mathrm{mg} / \mathrm{mL}, \mathrm{MBC}=0.78 \pm 1.25 \mathrm{mg} / \mathrm{mL}$ ) and the minimum antimicrobial activity was displayed by Commiphora molmol against Actinomyces naeslundii (MIC $=12.5 \pm 3.25 \mathrm{mg} / \mathrm{mL}$, $\mathrm{MBC}=100 \pm 3.75 \mathrm{mg} / \mathrm{mL}$ ). The best synergy was displayed by Commiphora molmol with fluconazole against Candida albicans $(\mathrm{FICI}=0.45)$. Conclusions: The current study delineates the variable antimicrobial activity of plant extracts against the experimental endodontic pathogenic microorganisms. Plant extracts in conjunction with various antimicrobials can be valuable aids in combating relatively resistant endodontic microorganisms that have been the cause of worry in recent years, leading to failure even in treatment procedures following all required protocols.

Keywords: endodontic pathogens; synergy; plant extracts; root canal treatment failure; antimicrobial activity 


\section{Introduction}

Enterococci are the most common bacteria found in the oral cavity, gastrointestinal tract, and vagina of humans and animals. Previously, Enterococci were regarded as nonvirulent, but now they are recognized as one of the major causes of nosocomial infections worldwide [1]. Enterococci are Gram-positive cocci that can occur singly, in pairs, or as short chains. They are facultative anaerobes, possessing the ability to grow in the presence or absence of oxygen. In endodontics, Enterococcus species, especially Enterococcus faecalis (E. faecalis), are associated with chronic periodontitis and failed root canal treatments involving chronic apical periodontitis [2,3].

Enterococcus pose a great challenge for dentists owing to their complex nature, which helps them to survive the harsh environments, including extreme alkaline $\mathrm{pH}$, salt concentrations and high temperatures of $60^{\circ} \mathrm{C}$ [4-6]. The principal cause for E. faecalis to be associated with endodontic failure is its ability to invade dentinal tubules and strong adhesion to collagen [7], which is abundantly present in root dentin and cementum. A confocal laser-scanning microscope showed that the depth of viable $E$. faecalis ranges from 100 to $400 \mu \mathrm{m}$ into dentinal tubules.

The virulence traits of E. faecalis are cell surface-associated protein, namely, enterococcal surface protein (ESP), secreted toxins, such as cytolysin, hemolysin, gelatinase, aggregation substance (AS), serine protease, and cell wall polysaccharide. These virulence traits are attributed to the pathogenicity islands, which are virulence-coding genes present on the genome. These genes encode for transposases, transcriptional regulators, and proteins are known to have potential roles in enhancing virulence [8]. E. faecalis has begun to pose a therapeutic challenge to physicians due to its ease of acquiring and transferring antimicrobial drug resistance. Management of such cases can sometimes be more demanding with the complex internal root canal anatomy of some teeth. However, this aspect has been greatly solved with the advent of cone-beam computed tomography (CBCT) in the field of endodontics [9-11].

Candida albicans (C. albicans) is a fungus usually seen in $21 \%$ of primary infections and $18 \%$ of retreatment cases $[12,13]$. Candida can survive in extreme environments by biofilm formation and using its physiochemical properties to suit the local conditions. This is the prime reason that it can persist in highly alkaline environments created by calcium hydroxide medications [14]. Actinomyces naeslundii (A. naeslundii) and other actinomyces species cause extra radicular infections [13]. While most extra-radicular infections are a sequel to intra-radicular ones, apical Actinomycosis, caused by Actinomyces species, is an example of extra-radicular infection independent of the intra-radicular infections [15]. This microorganism probably migrates from periapical tissues to infect the root canal system, but how this bacterium invades the periapical tissues is still controversial. It may result from not following the root canal treatment procedure in the recommended way leading to sepsis. Streptococcus mitis (S. mitis) is a Gram-positive coccus normally found in the oral cavity and can attach tooth surfaces by expressing specific proteins known as adhesins. Its cell wall contains peptidoglycans and lipoteichoic acids, which can influence inflammatory reactions and enhance pain modulation [16]. Streptococcus can invade dentinal tubules and, by releasing different extracellular proteins, can adapt and survive in adverse environmental conditions [17].

Salvadora persica (S. persica), also known as miswak, has antimicrobial properties and prevents E. faecalis bacteria from attaching the tooth surface [18]. It has also been shown to reduce Streptococcus mutans (S. mutans) count as fluoride interacts with bacterial glycolytic enzymes [19]. Because of its good antimicrobial properties [20] and low cytotoxicity can be used as a root canal irrigant as an alternative to sodium hypochlorite. Myrrh is a resin acquired as an exudate from the trunk of Commiphora molmol (C. molmol). Myrrh belongs to the family Burseraceae [21], which are trees that grow in sand and rocky areas in several countries like Saudi Arabia, Somalia, Sudan, Yemen, and Northeast Africa. C. molmol consists of $57-61 \%$ water-soluble gum, $25-40 \%$ alcohol-soluble resin, $7-17 \%$ volatile oil, and $3-4 \%$ impurities. In ancient times, it was used in inflammatory and 
infectious diseases. Azadirachta indica (A. indica), commonly known as neem, is a tree, which belongs to the Meliaceae family. It has many biological activities, such as antimicrobial, antiviral, antifungal, anti-inflammatory, antimalarial, antipyretic, antioxidant, analgesic, immune-stimulant, anti-fertility, anti-acne, antihypoglycemic, anti-cancer and nematicidal properties [22,23].

This study was aimed to evaluate the synergistic antimicrobial activity of extracts obtained from S. persica, C. molmol and A. indica combined with commercially available antimicrobial agents: penicillin, tetracycline, ofloxacin and fluconazole on endodontic pathogens, such as E. faecalis, S. mitis, A. naeslundii and C. albicans.

\section{Materials and Methods}

\subsection{Study Design and Protocol}

An in vitro experimental study design was used for the current study. Patients visiting the Department of Endodontics, College of Dentistry, King Khalid University, Saudi Arabia for retreatment of failed root canals from May 2018 to May 2019 were included in the study. The patients having radiological proof depicting apical periodontitis following diagnostic directions accepted by AAE [24] were included in this study. Patients with a history of smoking, periodontal pockets, pregnant women, and those having systemic conditions and taking antimicrobial drugs were excluded. Additionally, patients with missed canals, instrument separation, calcified canals and perforations were also excluded. Ethical approval (SRC/ETH/2017-18/085) was taken from the Research Ethics Committee, College of Dentistry, King Khalid University, Saudi Arabia, and written informed consent was obtained from the patients interested in voluntary participation.

Raw herbal products (roots and stems of S. persica, gum resin of C. molmol and bark of $A$. indica) were taken from the traditional market of Abha, Saudi Arabia. The reliability of the specimens was checked by the plant taxonomist. Various antimicrobials, such as penicillin, tetracycline, ofloxacin and fluconazole (Sigma-Aldrich, Merck KGaA, Darmstadt; Germany) in blend with various plant extracts were used to assess the presence of the collaborative effect. The detailed protocol of the study is depicted in the flowchart (Figure 1).

\subsection{Plants Extract Preparation}

The dried herbs of S. persica, C. molmol and A. indica were powdered using a grinder. Muslin cloth was used to pack $50 \mathrm{~g}$ of the powder and treated in a Soxhlet extractor using absolute ethanol for $72 \mathrm{~h}$ to perform hot extraction. Additionally, a muslin cloth was used to filter the ethanolic extract later by Whatman 1 filter paper. A rotary evaporator (Buchi Rotavapor R-200) was used to vaporize the filtrate underneath decreased pressure and temperature. In ethanol $(0.2 \mathrm{~g} / \mathrm{mL})$, dried plant extracts were dissolved again to be used in antimicrobial susceptibility assay. Preparation of stock solutions was done, and two-fold dilution of the stock ranging from $50 \mu \mathrm{g} / \mathrm{mL}$ to $0.2 \mathrm{~g} / \mathrm{mL}$ was used to achieve a final working volume to be later used in determining MIC and MBC/MFC.

\subsection{Clinical Examination and Sample Collection}

The teeth undergoing retreatment were assessed for their location, number of canals, and presenting signs and symptoms (pain, pus drainage through sinus tract, mobility and periodontal status). Intracoronal and extracoronal restorations were considered unacceptable if they had a marginal defect, fracture, secondary caries, or a dislodged restoration. A periapical radiograph was used to evaluate the condition of obturation [25]. An obturation was regarded as unacceptable if: (i) the obturation was more than $2 \mathrm{~mm}$ short of the apex or overextended beyond the apex; (ii) lateral space or voids were there in the obturation. Two investigators were assigned for the clinical evaluation. Samples from the root canals were taken using the procedure reported by Gomes et al. [16]. After rubber dam application, the concerned tooth was cleaned with $5.25 \%$ sodium hypochlorite, followed by $5 \%$ sodium thiosulfate. After removing the old restoration, the root canals were located, and the pulp chamber was cleaned with $5.25 \%$ sodium hypochlorite. The old obturation material was 
removed from the canals using H files (Dentsply Tulsa Dental, Tulsa, OK, USA) with sterile saline as an irrigant, and canal patency was obtained. Sterile paper points were used to take the microbial samples at full length in the canal for $30 \mathrm{~s}$. These paper points were then kept in a tube containing $1.5 \mathrm{~mL}$ of Gotenberg agar III as the transport medium.

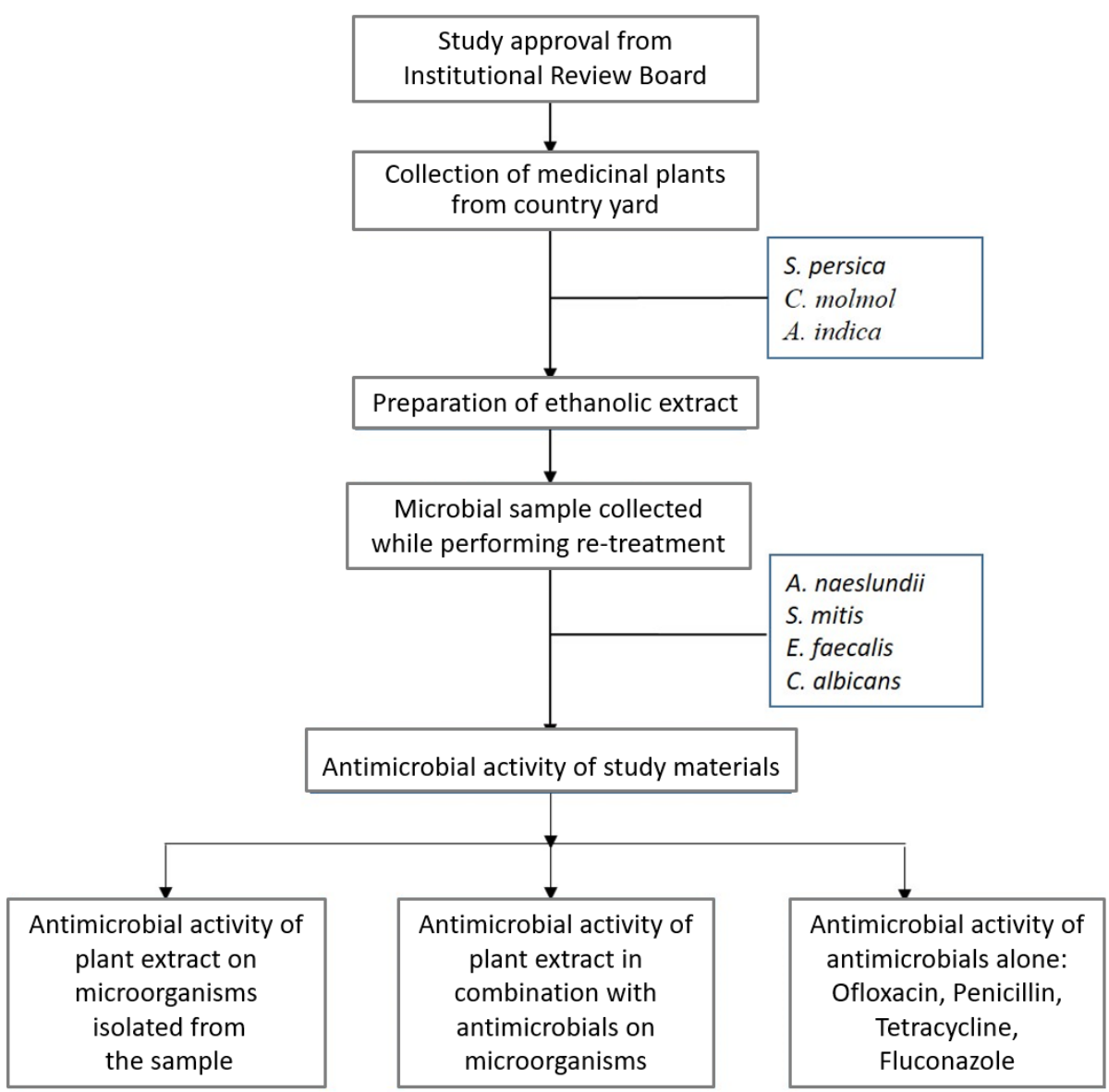

Figure 1. Flowchart of study design.

\subsection{Media for Microbial Growth}

Microbial growth and isolation were done in the specific culture media presented in Table 1. The microbial strains were further incubated at $37^{\circ} \mathrm{C}$ for $24-48 \mathrm{~h}$. The desired microbes grown on the media were further identified based on the colony morphology; biochemical tests were used to identify species.

Table 1. Selective media used.

\begin{tabular}{cl}
\hline Organisms & \multicolumn{1}{c}{ Media } \\
\hline E. faecalis & Enterococcosel agar (BBL Microbiological Systems, Cockeysville, MD, USA) \\
A. neslundii & Brain heart infusion agar (BHI agar, HiMedia, Mumbai, India) supplemented \\
S. mitis & with 10\% defibrinated sheep blood \\
C. albicans & Blood agar (Merck, Germany) \\
\hline
\end{tabular}

\subsection{Biochemical Tests for Microbial Identification}

An E. faecalis colony was isolated for identification by biochemical tests, such as VogesProsjauer, indole, citrate, urease, hydrogen sulfide (H2S) production and L-pyrrolidinyl arylamidase (PYR) test. A. neslundii and S. mitis were tested by API rapid ID32A kit (bioMérieux) as described by the manufacturer. They were also tested for esculin hydrolysis. 
Acid production from arabinose, fructose, cellobiose, inositol, glycogen, mannitol, lactose, ribose, and trehalose (at $1 \% w / v)$ and salicin and starch (at $0.5 \% w / v)$ in peptone-yeast extract broth was observed. C. albicans colonies showed a rough, filamentous border, composed of hyphae and pseudohyphae. C. albicans was identified by a germ tube test.

\subsection{Microbiological Assay}

2.6.1. Antimicrobial Susceptibility Assays of the Antimicrobial Agents

Disc diffusion method was used to examine antimicrobial sensitivity assay. Lysogeny broth (LB) media were used to inoculate cultures of microbes at $37^{\circ} \mathrm{C}$ for $3 \mathrm{~h}$. Phosphatebuffered saline was used to adjust turbidity to $0.5 \mathrm{McF}$ arland's index. Mueller-Hinton agar (MHA) plates were used for microbial lawn culture. MHA plates were used to place the selected antimicrobial plates (penicillin, tetracycline, ofloxacin and fluconazole) and incubated in suitable conditions at $37^{\circ} \mathrm{C}$ for $24 \mathrm{~h}$. The microbial growth inhibition zone was measured around each antimicrobial agent in millimeters as described [26].

\subsubsection{Antimicrobial Susceptibility Assays of the Plant Extracts}

The agar well diffusion method was used to examine the antimicrobial activity of the extracts. LB broth media was inoculated with cultures of microbes for $3 \mathrm{~h}$ at $37^{\circ} \mathrm{C}$, and 0.5 McFarland's index in phosphate-buffered saline was used to adjust the turbidity. The cap of the sterile syringe was used to prepare the wells of $6 \mathrm{~mm}$ diameter in LB agar, and a lawn culture was formed from a diluted culture with the help of a sterile cotton swab. The wells were filled with $20 \mu \mathrm{L}$ of extract from various plants $(0.2 \mathrm{~g} / \mathrm{mL})$ with incubation of the plates at $37^{\circ} \mathrm{C}$ for $24 \mathrm{~h}$. The diameter of the inhibition zone was measured around each well in millimeters as described [26]. The well for each microbe having $20 \mu \mathrm{L}$ of ethanol without any extracts was deliberated as control. The inhibition zone produced by plant extracts was subtracted from the inhibition zone produced by ethanol.

\subsubsection{Determination of MIC}

Micro-broth dilution assays using Mueller-Hinton broth were used to determine MICs of the plant extracts against microbial strains. The range of the extract's concentration was from $50 \mu \mathrm{g} / \mathrm{mL}$ to $0.2 \mathrm{~g} / \mathrm{mL}$. The wells of polystyrene sterile flat-bottomed 96-well plates were filled with $180 \mu \mathrm{L}$ culture of all microbial strains. The triplicate wells for each strain were loaded with $20 \mu \mathrm{L}$ from the 2-fold dilution of the plant extract. In the control group, the triplicate wells were loaded with $20 \mu \mathrm{L}$ of ethanol (5\%). Each strain had a starting inoculum of $1.5 \times 10^{5} \mathrm{CFU} / \mathrm{mL}$. MIC was considered as the lowest concentration of extracts that showed no visible microbial growth and turbidity after $24 \mathrm{~h}$ of incubation.

\subsubsection{Determination of $\mathrm{MBC} / \mathrm{MFC}$}

Subculturing of $100 \mu \mathrm{L}$ of the culture from each well of the micro-broth assay was done on MHA plates at $37^{\circ} \mathrm{C}$ for $24 \mathrm{~h}$ to obtain the MBC/MFC of the extracts. MBC/MFC was considered as the lowest concentration of the extracts at which there was no microbial growth.

\subsubsection{Synergistic Antimicrobial Assays}

The synergistic antimicrobial activity of the plant extracts was determined in combination with various antimicrobial agents by checkboard methods.

The antimicrobial activity of the plant extract and antimicrobial agent combination was interpreted as one of the following categories: synergy; additive effect, indifferent; or antagonism. The fractional inhibitory concentration (FIC) of each agent was calculated as the MIC of the agent in combination, divided by the MIC of the agent alone.

$$
\text { FIC }(a)=\frac{\text { MIC }(a) \text { in combination with }(b)}{\text { MIC }(a) \text { alone }}
$$




$$
\text { FIC }(b)=\frac{\text { MIC }(b) \text { in combination with }(a)}{\text { MIC }(b) \text { alone }}
$$

The sum of the FIC or FIC index (FICI) is therefore, analyzed as:

$$
\Sigma \text { FIC }=\text { FIC }(\mathrm{a})+\text { FIC }(\mathrm{b})
$$

The FICI results were interpreted as follows: $<0.5$ synergy; 0.5 to 1 additive effect; $1-2$ indifferent or no effect; and $>2$ antagonism [27].

\subsection{Statistical Analysis}

The experiments were conducted in triplicates. For the results, data were outlined as mean \pm standard deviation (SD). SPSS (version 11.5, Chicago) was used for statistical analysis. The significance of the difference between the mean expression of the experimental and the control samples was calculated using a one-tail Student's $t$-test.

\section{Results}

\subsection{Antimicrobial Activity of Antimicrobial Agents and Plant Extracts}

In this study, the screening activity of the antimicrobials against different strains was performed before evaluating the antimicrobial activity of the extracts from various plants. Tables 2 and 3 presented the outcomes of antimicrobial sensitivity of the various microbes to the antimicrobials used. During the experimental period, all the microbes were resistant to tetracycline. S. mitis was resistant to all the antimicrobials.

\begin{tabular}{|c|c|c|c|c|c|c|c|c|c|}
\hline \multirow[b]{2}{*}{ Organisms } & \multicolumn{3}{|c|}{ Penicillin $(10 \mu \mathrm{g})$} & \multicolumn{3}{|c|}{ Tetracycline $(30 \mu \mathrm{g})$} & \multicolumn{3}{|c|}{ Ofloxacin $(5 \mu \mathrm{g})$} \\
\hline & $\begin{array}{c}\text { Zone } \\
(\mathrm{mm}) \\
\text { Mean } \pm \text { SD }\end{array}$ & $\begin{array}{c}\text { MIC } \\
(\mu \mathrm{g} / \mathrm{mL}) \\
\text { Mean } \pm \text { SD }\end{array}$ & $\begin{array}{c}\text { MBC } \\
(\mu \mathrm{g} / \mathrm{mL}) \\
\text { Mean } \pm \mathrm{SD}\end{array}$ & $\begin{array}{c}\text { Zone } \\
(\mathrm{mm}) \\
\text { Mean } \pm \text { SD }\end{array}$ & $\begin{array}{c}\text { MIC } \\
(\mu \mathrm{g} / \mathrm{mL}) \\
\text { Mean } \pm \text { SD }\end{array}$ & $\begin{array}{c}\text { MBC } \\
(\mu \mathrm{g} / \mathrm{mL}) \\
\text { Mean } \pm \text { SD }\end{array}$ & $\begin{array}{c}\begin{array}{c}\text { Zone } \\
(\mathrm{mm})\end{array} \\
\text { Mean } \pm \mathrm{SD}\end{array}$ & $\begin{array}{c}\text { MIC } \\
(\mu \mathrm{g} / \mathrm{mL}) \\
\text { Mean } \pm \text { SD }\end{array}$ & $\begin{array}{c}\text { MBC } \\
(\mu \mathrm{g} / \mathrm{mL}) \\
\text { Mean } \pm \text { SD }\end{array}$ \\
\hline E. faecalis & $15 \pm 2.65(\mathrm{~S})$ & $5.5 \pm 1.5$ & $12 \pm 2.25$ & $0(\mathrm{R})$ & $8 \pm 0.75$ & $14.25 \pm 1.35$ & $17 \pm 2.65(\mathrm{~S})$ & $6 \pm 1.65$ & $10.28 \pm 3.25$ \\
\hline A. neslundii & $13 \pm 1.5(\mathrm{~S})$ & $2 \pm 1.5$ & $4.3 \pm 0.69$ & $3 \pm 0.5(\mathrm{R})$ & $2 \pm 1.45$ & $4.34 \pm 0.85$ & $15 \pm 1.5(\mathrm{~S})$ & $2 \pm 0.75$ & $5.5 \pm 1.65$ \\
\hline S. mitis & $0(\mathrm{R})$ & - & - & $0(\mathrm{R})$ & - & - & $2 \pm 0.75(\mathrm{R})$ & $1.9 \pm 1.35$ & $4.3 \pm 3.47$ \\
\hline
\end{tabular}

Table 2. Antimicrobial activity, MIC and MBC exhibited by antimicrobials against endodontic pathogenic microorganisms.

$\mathrm{MIC}=$ minimum inhibitory concentration; $\mathrm{MBC}=$ minimum bactericidal concentration; $\mathrm{S}=$ sensitivity; $\mathrm{R}=$ resistance; $\mathrm{SD}=$ standard deviation; - = no activity at the concentration of the antimicrobials used.

Table 3. Antifungal activity, MIC and MFC exhibited by fluconazole against C. albicans.

\begin{tabular}{cccc}
\hline \multirow{2}{*}{ Organisms } & \multicolumn{3}{c}{ Fluconazole $(\mathbf{1 0} \mu \mathrm{g})$} \\
\cline { 2 - 4 } & $\begin{array}{r}\text { Zone }(\mathbf{m m}) \\
\text { Mean } \pm \text { SD }\end{array}$ & $\begin{array}{c}\text { MIC }(\mu \mathrm{g} / \mathrm{mL}) \\
\text { Mean } \pm \text { SD }\end{array}$ & $\begin{array}{c}\text { MFC }(\mu \mathrm{g} / \mathrm{mL}) \\
\text { Mean } \pm \text { SD }\end{array}$ \\
\hline C.albicans & $24 \pm 2.75(\mathrm{~S})$ & $1 \pm 0.05$ & $2.15 \pm 0.35$
\end{tabular}

$\overline{\mathrm{MIC}}=$ minimum inhibitory concentration; $\mathrm{MFC}=$ minimum fungicidal concentration; $\mathrm{S}$ = sensitivity; $\mathrm{SD}=$ standard deviation.

To assess antimicrobial activity, the various plant extracts were used to treat all four microbes. A zone of inhibition was viewed as significant for susceptibility of the microbe to the plant extract if the zone size was more than $8 \mathrm{~mm}$. Table 4 presents the antimicrobial activity, MIC and MBC/MFC shown by various plant extracts against the tested microbes. All tested microbial strains were susceptible to ethanolic extracts of myrrh, while neem and miswak were found effective against all the tested microbes except $C$. albicans (Figure 2) $(p<0.05)$. 
Table 4. Antimicrobial activity, MIC and MBC/MFC exhibited by plant extract against endodontic pathogenic microorganisms.

\begin{tabular}{|c|c|c|c|c|c|c|c|c|c|c|}
\hline \multirow[b]{2}{*}{ Organisms } & \multicolumn{3}{|c|}{ A. indica } & \multicolumn{3}{|c|}{ S. persica } & \multicolumn{3}{|c|}{ C. molmol } & \multirow[b]{2}{*}{$p$-Value } \\
\hline & $\begin{array}{c}\begin{array}{c}\text { Zone } \\
(\mathrm{mm})\end{array} \\
\text { Mean } \pm \text { SD }\end{array}$ & $\begin{array}{c}\text { MIC }(\mathrm{mg} / \mathrm{mL}) \\
\text { Mean } \pm \text { SD }\end{array}$ & $\begin{array}{c}\mathrm{MBC} / \mathrm{MFC} \\
(\mathrm{mg} / \mathrm{mL}) \\
\text { Mean } \pm \mathrm{SD}\end{array}$ & $\begin{array}{c}\begin{array}{c}\text { Zone } \\
(\mathrm{mm})\end{array} \\
\text { Mean } \pm \text { SD }\end{array}$ & $\begin{array}{c}\mathrm{MIC}(\mathrm{mg} / \mathrm{mL}) \\
\text { Mean } \pm \mathrm{SD}\end{array}$ & $\begin{array}{c}\mathrm{MBC} / \mathrm{MFC} \\
(\mathrm{mg} / \mathrm{mL}) \\
\text { Mean } \pm \mathrm{SD}\end{array}$ & $\begin{array}{c}\begin{array}{c}\text { Zone } \\
(\mathrm{mm})\end{array} \\
\text { Mean } \pm \text { SD }\end{array}$ & $\begin{array}{c}\mathrm{MIC}(\mathrm{mg} / \mathrm{mL}) \\
\text { Mean } \pm \mathrm{SD}\end{array}$ & $\begin{array}{c}\mathrm{MBC} / \mathrm{MFC} \\
(\mathrm{mg} / \mathrm{mL}) \\
\text { Mean } \pm \mathrm{SD}\end{array}$ & \\
\hline E. faecalis & $14 \pm 1.5$ & $0.09 \pm 1.2$ & $0.78 \pm 1.25$ & $13 \pm 1.75$ & $6.25 \pm 2.25$ & $100 \pm 1.75$ & $17 \pm 1.25$ & $6.25 \pm 1.50$ & $100 \pm 2.0$ & 0.038 \\
\hline A. neslundii & $9 \pm 1.0$ & $4 \pm 0.5$ & $16 \pm 0.65$ & $20 \pm 2.0$ & $8.65 \pm 0.50$ & $12.34 \pm 1.0$ & $13 \pm 0.75$ & $12.5 \pm 3.25$ & $100 \pm 3.75$ & 0.013 \\
\hline S. mitis & $10 \pm 0.75$ & $6.25 \pm 0.24$ & $100 \pm 2.5$ & $12 \pm 1.25$ & $6.25 \pm 1.5$ & $50 \pm 1.5$ & $15 \pm 2.75$ & $3.25 \pm 2.25$ & $50 \pm 2.25$ & 0.031 \\
\hline C. albicans & - & - & - & - & - & - & $14 \pm 0.68$ & $3.12 \pm 0.75$ & $25 \pm 1.5$ & 0.179 \\
\hline
\end{tabular}

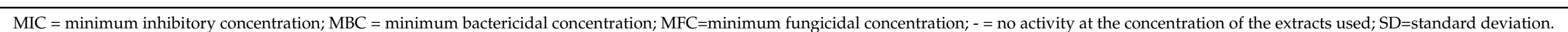




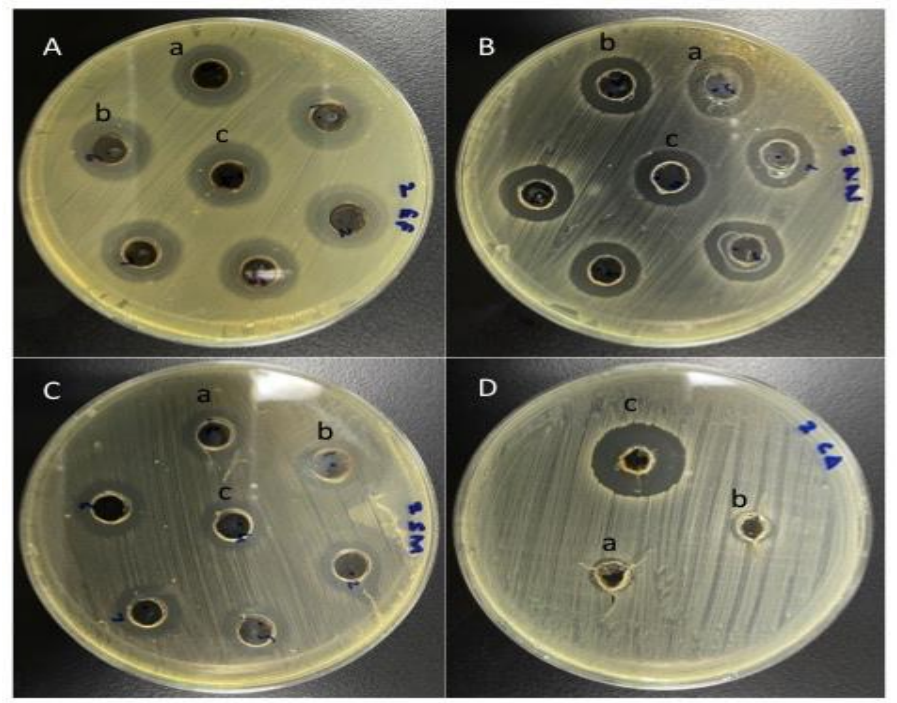

Figure 2. Antimicrobial activity of plant extracts A. indica, S. persica and C. molmol against the microbial strains (A) E. faecalis (B) A. neslundii (C) S. mitis (D) C. albicans.

\subsection{MIC and $M B C / M F C$ of Plant Extracts}

To compare the effects of various plant extracts on microbial growth, MIC and $\mathrm{MBC} / \mathrm{MFC}$ of these extracts were considered. Since the diffusion and absorption of extract-bioactive compounds may curb the effects on microbial proliferation, they were not considered in the method of liquid dilution. It was found that all the microbial strains were susceptible to myrrh $(p<0.05)$, while $C$. albicans was not susceptible to neem and miswak extract $(p=0.179)$. The highest MIC and MBC value was displayed by $C$. molmol against $A$. neslundii, whereas the lowest MIC and MBC value was displayed by $A$. indica against $E$. faecalis (Table 4).

\subsection{Synergistic Activity of Plant Extracts with Antimicrobial Agents}

The best effect of $A$. indica was against $E$. faecalis, where it showed additive effect when it was combined with penicillin, tetracycline and ofloxacin. It also exhibited an additive effect with ofloxacin against $S$. mitis. Combination of $A$. indica with penicillin, tetracycline and ofloxacin showed no effect against $A$. neslundii. (Table 5).

Table 5. Synergistic antimicrobial activity of $A$. indica with various antimicrobial agents.

\begin{tabular}{|c|c|c|c|c|c|c|c|}
\hline \multirow[t]{2}{*}{ Organisms } & \multirow[t]{2}{*}{ Antibiotics } & \multicolumn{2}{|c|}{$\begin{array}{l}\text { MIC of Antimicrobial } \\
\text { Agents }(\mu \mathrm{g} / \mathrm{mL})\end{array}$} & \multicolumn{2}{|c|}{$\begin{array}{l}\text { MIC of } A . \text { indica } \\
\quad(\mathrm{mg} / \mathrm{mL})\end{array}$} & \multirow[t]{2}{*}{ FICI } & \multirow[t]{2}{*}{ Interpretation } \\
\hline & & Alone & Combination & Alone & Combination & & \\
\hline \multirow{4}{*}{ E. faecalis } & Penicillin & 5.5 & 2.5 & 0.9 & 0.035 & 0.83 & Additive \\
\hline & Tetracycline & 8 & 4 & 0.9 & 0.042 & 0.96 & Additive \\
\hline & Ofloxacin & 6 & 3.75 & 0.9 & 0.06 & 0.88 & Additive \\
\hline & Penicillin & 2 & 1.5 & 4 & 1.95 & 1.23 & Indifferent \\
\hline \multirow{2}{*}{ A. naeslundii } & Tetracycline & 2 & 0.75 & 4 & 3.25 & 1.18 & Indifferent \\
\hline & Ofloxacin & 2 & 1.25 & 4 & 1.55 & 1.005 & Indifferent \\
\hline \multirow{3}{*}{ S. mitis } & Penicillin & - & - & - & - & - & - \\
\hline & Tetracycline & - & - & - & - & - & - \\
\hline & Ofloxacin & 1.9 & 0.65 & 6.25 & 1.75 & 0.62 & Additive \\
\hline
\end{tabular}

MIC = minimum inhibitory concentration; FICI = fractional inhibitory concentration index; - = no activity.

The combination of S. persica with penicillin showed an additive effect against $E$. faecalis, while it showed an additive effect against $A$. neslundii when it was combined with tetracycline and ofloxacin. No effect of $S$. persica was observed against E. faecalis and $A$. 
neslundii when it combined with tetracycline, ofloxacin and penicillin, respectively. In the case of S. mitis, when S. persica was combined with ofloxacin, it exhibited a synergistic effect. (Table 6).

Table 6. Synergistic antimicrobial activity of s. persica with various antimicrobial agents.

\begin{tabular}{|c|c|c|c|c|c|c|c|}
\hline \multirow[t]{2}{*}{ Organisms } & \multirow[t]{2}{*}{ Antibiotics } & \multicolumn{2}{|c|}{$\begin{array}{l}\text { MIC of Antimicrobial } \\
\text { Agents }(\mu \mathrm{g} / \mathrm{mL})\end{array}$} & \multicolumn{2}{|c|}{$\begin{array}{l}\text { MIC of S. persica } \\
\quad(\mathrm{mg} / \mathrm{mL})\end{array}$} & \multirow[t]{2}{*}{ FICI } & \multirow[t]{2}{*}{ Interpretation } \\
\hline & & Alone & Combination & Alone & Combination & & \\
\hline \multirow{4}{*}{ E. faecalis } & Penicillin & 5.5 & 2.5 & 6.25 & 2.15 & 0.79 & Additive \\
\hline & Tetracycline & 8 & 4 & 6.25 & 4.25 & 1.18 & Indifferent \\
\hline & Ofloxacin & 6 & 3.75 & 6.25 & 3.5 & 1.185 & Indifferent \\
\hline & Penicillin & 2 & 1.5 & 8.65 & 8.65 & 1.75 & Indifferent \\
\hline \multirow[t]{2}{*}{ A. naeslundii } & Tetracycline & 2 & 0.75 & 8.65 & 2.35 & 0.64 & Additive \\
\hline & Ofloxacin & 2 & 1.25 & 8.65 & 2.5 & 0.91 & Additive \\
\hline \multirow{3}{*}{ S. mitis } & Penicillin & - & - & - & - & - & - \\
\hline & Tetracycline & - & - & - & - & - & - \\
\hline & Ofloxacin & 1.9 & 0.65 & 6.25 & 0.95 & 0.49 & Synergistic \\
\hline
\end{tabular}

MIC = minimum inhibitory concentration; FICI = fractional inhibitory concentration index; $-=$ no activity.

C. molmol had a synergy with ofloxacin against $S$. mitis and with fluconazole against C. albicans. It showed an additive effect against $E$. faecalis in combination with penicillin, tetracycline and ofloxacin. At the same time, it exhibited no effect in combination of penicillin and ofloxacin against $A$. neslundii (Table 7).

Table 7. Synergistic antimicrobial activity of C. molmol with various antimicrobial agents.

\begin{tabular}{|c|c|c|c|c|c|c|c|}
\hline \multirow[t]{2}{*}{ Organisms } & \multirow[t]{2}{*}{ Antibiotics } & \multicolumn{2}{|c|}{$\begin{array}{l}\text { MIC of Antimicrobial } \\
\text { Agents }(\mu \mathrm{g} / \mathrm{mL})\end{array}$} & \multicolumn{2}{|c|}{$\begin{array}{l}\text { MIC of C. molmol } \\
(\mathrm{mg} / \mathrm{mL})\end{array}$} & \multirow[t]{2}{*}{ FICI } & \multirow[t]{2}{*}{ Interpretation } \\
\hline & & Alone & Combination & Alone & Combination & & \\
\hline \multirow{3}{*}{ E. faecalis } & Penicillin & 5.5 & 2.5 & 6.25 & 0.40 & 0.51 & Additive \\
\hline & Tetracycline & 8 & 4 & 6.25 & 0.45 & 0.57 & Additive \\
\hline & Ofloxacin & 6 & 3.75 & 6.25 & 0.58 & 0.71 & Additive \\
\hline \multirow{4}{*}{ A. naeslundii } & Penicillin & 2 & 1.5 & 12.5 & 0.25 & 1.25 & Indifferent \\
\hline & Tetracycline & 2 & 0.75 & 12.5 & 2.21 & 0.54 & Additive \\
\hline & Ofloxacin & 2 & 1.25 & 12.5 & 9.75 & 1.40 & Indifferent \\
\hline & Penicillin & - & - & - & - & - & - \\
\hline \multirow[t]{2}{*}{ S. mitis } & Tetracycline & - & - & - & - & - & - \\
\hline & Ofloxacin & 1.9 & 0.65 & 3.25 & 0.5 & 0.49 & Synergistic \\
\hline C. albicans & Fluconazole & 1 & 0.31 & 3.12 & 0.44 & 0.45 & Synergistic \\
\hline
\end{tabular}

$\mathrm{MIC}=$ minimum inhibitory concentration; $\mathrm{FICI}=$ fractional inhibitory concentration index; $-=$ no activity.

\section{Discussion}

In the last 15 years, the role of stem cells has given a major boost to various dental regenerative procedures for repairing dental and other oral defects [28-30]. However, all these procedures require aseptic conditions, which is greatly altered by the presence of pathogenic oral microorganisms. The study was conducted on E. faecalis, S. mitis, $A$, neslundii, and C. Albicans as these microorganisms are commonly responsible for the failure of the root canal treatment procedure and result in persistent post-treatment apical periodontitis [15,16,31-35].

The aim of this in vitro study was to investigate synergies between plant extracts of C. molmol, $A$. indica and S. persica with various antimicrobials against endodontic pathogenic microorganisms, such as E. faecalis, S. mitis, A. neslundii and C. albicans. E. faecalis can be found as the only microorganism in the root canal treated teeth with periapical pathology $[34,36]$. Its frequency is higher in persistent peri-radicular infections and almost nine 
times in failed root canals than primary endodontic infections [37]. In C. albicans, dimorphic switching plays an important role in its pathogenicity and biofilm formation $[38,39]$.

Ethanol was used as a solvent to withdraw the vital compounds from the plant products following the previous studies [40-42]. The existence of saponins, steroids, tannic acid, alkaloids, flavonoids, glycosides and anthraquinone renders antimicrobial properties of $A$. indica (neem) [43]. Several studies have demonstrated the antimicrobial effect of $A$. indica on E. faecalis [44-46]. An in vitro study found that the antimicrobial effect of $A$. indica against $C$. albicans followed sodium hypochlorite and propolis [47]. On the contrary, in the present study, $A$. indica demonstrated antimicrobial property against all endodontic pathogenic microbes $(p<0.05)$ except the $C$. albicans $(p=0.179)$. The antibacterial activity of neem was the most against $E$. faecalis (MIC $=0.09 \pm 1.2 \mathrm{mg} / \mathrm{mL}$, $\mathrm{MBC}=0.78 \pm 1.25 \mathrm{mg} / \mathrm{mL}$ ) followed by $A$. neslundii $(\mathrm{MIC}=4 \pm 0.5 \mathrm{mg} / \mathrm{mL}$, $\mathrm{MBC}=16 \pm 0.65 \mathrm{mg} / \mathrm{mL}$ ) and S. mitis (MIC $=6.25 \pm 0.24 \mathrm{mg} / \mathrm{mL}$, $\mathrm{MBC}=100 \pm 2.5 \mathrm{mg} / \mathrm{mL}$ ).

Miswak in the form of chewing sticks, due to their antibacterial, antifungal, antiviral, and antiplaque properties, have a widespread application in and around Middle Eastern countries [20]. Against oral pathogens, it has effectively reduced the count of E. faecalis, S. mutans, L. acidophilus and P. aeruginosa [48,49]. In the present study, Miswak showed antimicrobial properties against all the pathogens other than C. albicans. The highest antibacterial activity of miswak was displayed against $S$. mitis (MIC $=6.25 \pm 1.5 \mathrm{mg} / \mathrm{mL}$, $\mathrm{MBC}=50 \pm 1.5$ ) followed by $E$. faecalis (MIC $=6.25 \pm 2.25 \mathrm{mg} / \mathrm{mL}$, $\mathrm{MBC}=100 \pm 1.75 \mathrm{mg} / \mathrm{mL}$ ) and A. neslundii (MIC $=8.65 \pm 0.50 \mathrm{mg} / \mathrm{mL}$, $\mathrm{MBC}=12.34 \pm 1.0 \mathrm{mg} / \mathrm{mL}$ ).

Myrrh has been investigated for its antimicrobial properties against oral pathogens and found to have promising results against E. faecalis, F. nucleatum [50] and helping in the reduction of plaque and gingival inflammation. In the current study, myrrh was the only plant extract that was an effective antimicrobial against all the experimental pathogens. It displayed the highest antimicrobial effect against C. albicans (MIC $=3.12 \pm 0.75 \mathrm{mg} / \mathrm{mL}$, $\mathrm{MFC}=25 \pm 1.5 \mathrm{mg} / \mathrm{mL}$ ) followed by $S$. mitis $(\mathrm{MIC}=3.25 \pm 2.25 \mathrm{mg} / \mathrm{mL}$, $\mathrm{MBC}=50 \pm 2.25 \mathrm{mg} / \mathrm{mL}$ ), E. faecalis (MIC $=6.25 \pm 1.50 \mathrm{mg} / \mathrm{mL}, \mathrm{MBC}=100 \pm 2.0 \mathrm{mg} / \mathrm{mL}$ ) and $A$. neslundii (MIC $=12.5 \pm 3.25 \mathrm{mg} / \mathrm{mL}, \mathrm{MBC}=100 \pm 3.75 \mathrm{mg} / \mathrm{mL}$ ).

The effect of combining two drugs can be antagonistic, indifferent, additive, or synergistic. Few previous in vitro studies have evaluated the effects of combining various antibiotics with different plant extracts that have reduced MIC for antibiotics [51,52]. One of the important aspects of the current study was to evaluate the effect of combining the various antimicrobial drugs with different plant extracts on endodontic pathogens responsible for root canal failure, which may be helpful in the development of a better and new protocol for treating complex endodontic cases. Neem had displayed an additive effect with penicillin ( $\mathrm{FICI}=0.83)$, tetracycline $(\mathrm{FICI}=0.96)$, ofloxacin $(\mathrm{FICI}=0.88)$ against E. faecalis, while for $A$. neslundii it was indifferent with penicillin $(\mathrm{FICI}=1.23)$, tetracycline $(\mathrm{FICI}=1.18)$ and ofloxacin $(\mathrm{FICI}=1.005)$. The best effect of combining various plant extracts with different antimicrobials against $E$. faecalis was an additive effect of combining C. molmol with penicillin $(\mathrm{FICI}=0.51$ ), which was followed by $C$. molmol with tetracycline $(\mathrm{FICI}=0.57)$ and $C$. molmol with ofloxacin $(\mathrm{FICI}=0.71)$. Miswak was effective against S. mitis in synergy with ofloxacin $(\mathrm{FICI}=0.49)$. Against $A$. neslundii, it had an additive effect with tetracycline (FICI $=0.64$ ) and ofloxacin (FICI $=0.91)$, and against $E$. faecalis, it had an additive effect with penicillin $(\mathrm{FICI}=0.79)$. The best effect of combining various plant extracts with different antimicrobials against $A$. neslundii was an additive effect of combining $C$. molmol with tetracycline $(\mathrm{FICI}=0.54$ ), which was followed by $S$. persica with tetracycline $(\mathrm{FICI}=0.64)$ and . persica with ofloxacin $(\mathrm{FICI}=0.91)$. Myrrh was in synergy with ofloxacin and fluconazole against both $S$. mitis $(\mathrm{FICI}=0.49)$ and $C$. albicans $(\mathrm{FICI}=0.45)$, respectively. It exhibited an additive effect against $E$. faecalis with all the three antimicrobials: penicillin $(\mathrm{FICI}=0.51)$, tetracycline $(\mathrm{FICI}=0.57)$, ofloxacin $(\mathrm{FICI}=0.71)$, while an indifferent effect was observed against $A$. neslundii with penicillin $(\mathrm{FICI}=1.25)$ 
and ofloxacin $(\mathrm{FICI}=1.40)$. The best effects of combining various plant extracts with different antimicrobials against $S$. mitis were the synergistic effect of $C$. molmol with ofloxacin $(\mathrm{FICI}=0.49)$ and $S$. persica with ofloxacin $(\mathrm{FICI}=0.49)$. Against $C$. albicans, the synergistic effect of $C$. molmol with fluconazole, was the best synergistic effect $(\mathrm{FICI}=0.45)$ against the different microbes tested with various combinations.

Tetracyclines, being broad-spectrum antibiotics, are used as intracanal antibiotics against polymicrobial endodontic microorganisms, along with others like metronidazole and newer BioPure MTAD (Dentsply Sirona, Salzburg, Austria). However, intracanal microorganisms are resistant to these antibiotics [53-55], and in some cases, tetracycline may even promote the growth of C. albicans [56]. This problem of antimicrobial resistance can be effectively managed by using the combination of plant extracts with antimicrobial agents. Along with this, they can be used alone for intracanal irrigation as an alternative to sodium hypochlorite, which has many disadvantages like toxicity, bad taste, and accident mishaps. Further, more evidence gained with future studies combining these plant extracts with antimicrobials may help with other dental procedures like pulp capping, regenerative endodontics and managing traumatic injuries like luxation and tooth avulsion.

\section{Conclusions}

The results from the study indicate that plants in the form of their extracts are good sources of biologically active antimicrobial agents. Plant extracts in conjunction with various antimicrobial agents can be a valuable aid in combating the relatively resistant endodontic microorganisms that have been the cause of worry in recent years leading to failure even in the treatment procedures following all the required protocols. The current study clearly indicates the effectiveness of all the three plant extracts, C. molmol, A. indica, S. persica, against all the experimental endodontic pathogenic microorganisms. A. indica and $S$. persica were ineffective against $C$. albicans. Synergies of plant extracts with antimicrobials helped enhance overall antimicrobial effects. The best synergy was displayed by C. molmol with fluconazole against $C$. albicans. In addition, $C$. molmol and S. persica both exhibited synergy with ofloxacin against $S$. mitis. The effects of synergies may help in improving the treatment modalities against endodontic pathogens. However, further studies are needed to evaluate their biocompatibility, effect on biofilms and their mechanisms for synergy.

Author Contributions: Conceptualization, S.A., S.A.S., I.A.; methodology, P.S., M.A.K., M.YA.; formal analysis, M.A.K., M.YA., Y.AA., S.S.B.; investigation, I.A., S.A., A.M.A., S.S.B.; resources, S.A.S., I.A., Y.AA., S.A.; data curation, P.S., S.A.S., Y.AA., S.M.B.; writing-original draft preparation, S.A., P.S., I.A., M.YA.; writing-review and editing, S.A.S., M.A.K., S.M.B.; supervision, I.A., M.YA., A.M.A.; project administration, S.A, S.A.S, Y.AA., M.A.K.; funding acquisition, S.A., M.A.K., S.S.B. All authors reviewed the manuscript. All authors have read and agreed to the published version of the manuscript.

Funding: The authors received funding from the Deanship of Scientific Research at King Khalid University through General Research Project under grant number (GRP-164/1441).

Institutional Review Board Statement: The study was conducted according to the guidelines of the Declaration of Helsinki and approved by the Research Ethics Committee, College of Dentistry, King Khalid University (reference number: SRC/ETH/2017-2018/085).

Informed Consent Statement: Informed consent was obtained from all subjects involved in the study.

Data Availability Statement: The data presented in this study are available on reasonable request from the corresponding author. The data are not publicly available due to privacy restrictions.

Acknowledgments: The authors extend their appreciation to the Deanship of Scientific Research at King Khalid University for funding this work through General Research Project under grant number (GRP-164/1441).

Conflicts of Interest: The authors declare that they have no conflict of interest. 


\section{References}

1. Kayaoglu, G.; Orstavik, D. Virulence factors of Enterococcus faecalis: Relationship to endodontic disease. Crit. Rev. Oral Biol. Med. 2004, 15, 308-320. [CrossRef]

2. Souto, R.; Colombo, A.P. Prevalence of Enterococcus faecalis in subgingival biofilm and saliva of subjects with chronic periodontal infection. Arch. Oral Biol. 2008, 53, 155-160. [CrossRef]

3. Ahmad, I.; Wahab, S.; Nisar, N.; Dera, A.A.; Alshahrani, M.Y.; Abullias, S.S.; Irfan, S.; Alam, M.M.; Srivastava, S. Evaluation of antibacterial properties of Matricaria aurea on clinical isolates of periodontitis patients with special reference to red complex bacteria. Saudi Pharm. J. 2020, 28, 1203-1209. [CrossRef] [PubMed]

4. $\quad$ Flahaut, S.; Benachour, A.; Giard, J.-C.; Boutibonnes, P.; Auffray, Y. Defence against lethal treatments and de novo pro-tein synthesis induced by $\mathrm{NaCl}$ in Enterococcus faecalis ATC C19433. Arch. Microbiol. 1996, 165, 317-324. [CrossRef] [PubMed]

5. Flahaut, S.; Hartke, A.; Giard, J.-C.; Auffray, Y. Alkaline stressresponse in Enterococcus faecalis: Adaptation, cross-protection, and changes in protein synthesis. Appl. Environ. Microbiol. 1997, 63, 812-814. [CrossRef]

6. Flahaut, S.; Hartke, A.; Giard, J.-C.; Benachour, A.; Boutibonnes, P.; Auffray, Y. Relationship between stress responsetowards bile salts, acid and heat treatment in Enterococcusfaecalis. FEMS Microbiol. Lett. 1996, 138, 49-54. [CrossRef]

7. Hubble, T.S.; Hatton, J.F.; Nallapareddy, S.R.; Murray, B.E.; Gillespie, M.J. Influence of Enterococcus faecalis proteases and the collagen-binding protein, Ace, on adhesion to dentin. Oral Microbiol. Immunol. 2003, 18, 121-126. [CrossRef]

8. Banerjee, T.; Anupurba, S. Prevalence of virulence factors and drug resistance in clinical isolates of Enterococci: A study from North India. J. Pathog. 2015, 2015, 692612. [CrossRef] [PubMed]

9. Sberna, M.T.; Rizzo, G.; Zacchi, E.; Capparè, P.; Rubinacci, A. A preliminary study of the use of peripheral quantitative computed tomography for investigating root canal anatomy. Int. Endod. J. 2009, 42, 66-75. [CrossRef]

10. Bueno, M.R.; Estrela, C.; Granjeiro, J.M.; Estrela, M.; Azevedo, B.C.; Diogenes, A. Cone-beam computed tomography cinematic rendering: Clinical, teaching and research applications. Braz. Oral Res. 2021, 35, e024. [CrossRef]

11. Ahmed, H.; Ibrahim, N.; Mohamad, N.S.; Nambiar, P.; Muhammad, R.F.; Yusoff, M.; Dummer, P. Application of a new system for classifying root and canal anatomy in studies involving micro-computed tomography and cone beam computed tomographyExplanation and elaboration. Int. Endod. J. 2021. [CrossRef]

12. Baumgartner, J.C.; Watts, C.M.; Xia, T. Occurrence of Candida albicans in infections of endodontic origin. J. Endod. 2000, 26, 695-698. [CrossRef] [PubMed]

13. Siqueira, J.F., Jr.; Rôças, I.N. Diversity of endodontic microbiota revisited. J. Dent. Res. 2009, 88, 969-981. [CrossRef] [PubMed]

14. Waltimo, T.M.; Haapasalo, M.; Zehnder, M.; Meyer, J. Clinical aspects related to endodontic yeast infections. Endod. Top. 2004, 9 , 66-78. [CrossRef]

15. Siqueira, J.F., Jr. Periapical actinomycosis and infection with Propionibacterium propionicum. Endod. Top. 2003, 6, 78-95. [CrossRef]

16. Gomes, B.P.; Pinheiro, E.T.; Gadê-Neto, C.R.; Sousa, E.L.; Ferraz, C.C.; Zaia, A.A.; Teixeira, F.B.; Souza-Filho, F.J. Microbiological examination of infected dental root canals. Oral Microbiol. Immunol. 2004, 19, 71-76. [CrossRef]

17. Chávez de Paz, L.; Svensäter, G.; Dahlén, G.; Bergenholtz, G. Streptococci from root canals in teeth with apical periodontitis receiving endodontic treatment. Oral Surg. Oral Med. Oral Pathol. Oral Radiol. Endod. 2005, 100, 232-241. [CrossRef] [PubMed]

18. Almas, K. The antimicrobial effects of extracts of Azadirachta indica (neem) and Salvadora Persica (Arak) chewing sticks. Indian J. Dent. Res. 1999, 10, 23-26.

19. Halawany, H.S. A review on miswak (Salvadora persica) and its effect on various aspects of oral health. Saudi Dent. J. 2012, 24, 63-69. [CrossRef]

20. Haque, M.M.; Alsareii, S.A. A review of the therapeutic effects of using miswak (Salvadora Persica) on oral health. Saudi Med. J. 2015, 36, 530-543. [CrossRef]

21. Dolara, P.; Corte, B.; Ghelardini, C.; Pugliese, A.M.; Cerbai, E.; Menichetti, S.; Lo Nostro, A. Local anaesthetic, antibacterial and antifungal properties of sesquiterpenes from myrrh. Planta Med. 2000, 66, 356-358. [CrossRef] [PubMed]

22. Ghonmode, W.N.; Balsaraf, O.D.; Tambe, V.H.; Saujanya, K.P.; Patil, A.K.; Kakde, D.D. Comparison of the antibacterial efficacy of neem leaf extracts, grape seed extracts and 3\% sodium hypochlorite against E. faecalis-An in vitro study. J. Int. Oral Health 2013, 5, 61-66.

23. Ahmad, I. Antibacterial activity of Nepeta deflersiana extract against pathogenic Gram-positive bacteria. Res. J. Biotechnol. 2019, 14, 43-51.

24. Kaufman, B.; Spångberg, L.; Barry, J.; Fouad, A.F. Enterococcus spp. in endodontically treated teeth with and without periradicular lesions. J. Endod. 2005, 31, 851-856. [CrossRef]

25. Dugas, N.N.; Lawrence, H.P.; Teplitsky, P.E.; Pharoah, M.J.; Friedman, S. Periapical health and treatment quality assessment of root-filled teeth in two Canadian populations. Int. Endod. J. 2003, 36, 181-192. [PubMed]

26. Al-Kuraishy, H.M.; Al-Gareeb, I.; Albuhadilly, K.A.; Alwindy, S. In vitro assessment of the antibacterial activity of Matricaria chamomile alcoholic extract against pathogenic bacterial strains. Br. Microbiol. Res. J. 2015, 7, 55-61. [CrossRef]

27. Ahmad, A.; van Vuuren, S.; Viljoen, A. Unravelling the complex antimicrobial interactions of essential oils-the case of Thymus vulgaris (Thyme). Molecules 2014, 19, 2896-2910.

28. Capparè, P.; Tetè, G.; Sberna, M.T.; Panina-Bordignon, P. The Emerging Role of Stem Cells in Regenerative Dentistry. Curr. Gene Ther. 2020, 20, 259-268. [PubMed] 
29. Khazaei, S.; Keshavarz, G.; Bozorgi, A.; Nazari, H.; Khazaei, M. Adipose tissue-derived stem cells: A comparative review on isolation, culture, and differentiation methods. Cell Tissue Bank 2021. [CrossRef]

30. Sanz, J.L.; Rodríguez-Lozano, F.J.; Lopez-Gines, C.; Monleon, D.; Llena, C.; Forner, L. Dental stem cell signaling pathway activation in response to hydraulic calcium silicate-based endodontic cements: A systematic review of in vitro studies. Dent. Mater. 2021, 37, e256-e268. [PubMed]

31. Peciuliene, V.; Reynaud, A.H.; Balciuniene, I.; Haapasalo, M. Isolation of yeasts and enteric bacteria in root-filled teeth with chronic apical periodontitis. Int. Endod. J. 2001, 34, 429-434. [CrossRef] [PubMed]

32. Pinheiro, E.T.; Gomes, B.P.; Ferraz, C.C.; Sousa, E.L.; Teixeira, F.B.; Souza-Filho, F.J. Microorganisms from canals of root-filled teeth with periapical lesions. Int. Endod. J. 2003, 36, 1-11. [CrossRef] [PubMed]

33. Waltimo, T.M.; Sen, B.H.; Meurman, J.H.; Uırstavik, D.; Haapasalo, M.P. Yeasts in apical periodontitis. Crit. Rev. Oral Biol. Med. 2003, 14, 128-137. [CrossRef]

34. Pinheiro, E.T.; Gomes, B.P.; Ferraz, C.C.; Teixeira, F.B.; Zaia, A.A.; Souza Filho, F.J. Evaluation of root canal microorganisms isolated from teeth with endodontic failure and their antimicrobial susceptibility. Oral Microbiol. Immunol. 2003, 18, 100-103. [CrossRef]

35. Siqueira, J.F.; Rôças, I. Polymerase chain reaction-based analysis of microorganisms associated with failed endodontic treatment. Oral Surg. Oral Med. Oral Pathol. Oral Radiol. Endod. 2004, 97, 85-94.

36. Sundqvist, G.; Figdor, D.; Persson, S.; Sjögren, U. Microbiologic analysis of teeth with failed endodontic treatment and the outcome of conservative re-treatment. Oral Surg. Oral Med. Oral Pathol. Oral Radiol. Endod. 1998, 85, 86-93.

37. Rôças, I.N.; Siqueira, J.F.; Santos, K.R.N. Association of Enterococcus faecalis with different forms of periradicular diseases. J. Endod. 2004, 30, 315-320. [PubMed]

38. Nikawa, H.; Nishimura, H.; Hamada, T.; Makihira, S.; Samaranayake, L.P. Relationship between thigmotropism and candida biofilm formation in vitro. Mycopathologia 1998, 144, 125-129. [CrossRef]

39. Davies, J.M.; Stacey, A.J.; Gilligan, C.A. Candida albicans hyphal invasion: Thigmotropism or chemotropism? FEMS Microbiol. Lett. 1999, 171, 245-249.

40. Jaisinghani, R.N.; Makhwana, S.; Kanojia, A. Study on antibacterial and flavonoid content of ethanolic extract of Punica granatum (pomegranate) peel. Microbiol. Res. 2018, 9, 6-9.

41. Lakshmi, T.; Aravind, K.S. Antibacterial evaluation of AzadirachtaIndica ethanolic leaf extract against selected acidogenic oral bacteria causing dental plaque in fixed orthodontic appliance patients—An Invitro study. Int. J. Bot. Res. 2012, 1, 30-40.

42. Kuete, V. Potential of Cameroonian plants and derived products against microbial infections: A review. Planta Med. 2010, 76, 1479-1491. [CrossRef] [PubMed]

43. Saquib, S.A.; AlQahtani, N.A.; Ahmad, I.; Kader, M.A.; Al Shahrani, S.S.; Asiri, E.A. Evaluation and Comparison of Antibacterial Efficacy of Herbal Extracts in Combination with Antibiotics on Periodontal pathobionts: An in vitro Microbiological Study. Antibiotics 2019, 1, 89. [CrossRef]

44. Arévalo-Híjar, L.; Aguilar-Luis, M.Á.; Caballero-García, S.; Gonzáles-Soto, N.; Valle-Mendoza, D. Antibacterial and Cytotoxic Effects of Moringa oleifera (Moringa) and Azadirachta indica (Neem) Methanolic Extracts against Strains of Enterococcus faecalis. Int. J. Dent. 2018, 3, 1-5. [CrossRef] [PubMed]

45. Chandrappa, P.M.; Dupper, A.; Tripathi, P.; Arroju, R.; Sharma, P.; Sulochana, K. Antimicrobial activity of herbal medicines (tulsi extract, neem extract) and chlorhexidine against Enterococcus faecalis in Endodontics: An in vitro study. J. Int. Soc. Prevent. Community Dent. 2015, 5 (Suppl. 2), S89-S92.

46. Mistry, K.S.; Sanghvi, Z.; Parmar, G.; Shah, S. The antimicrobial activity of Azadirachta indica, Mimusops elengi, Tinospora cardifolia, Ocimum sanctum and $2 \%$ chlorhexidine gluconate on common endodontic pathogens: An in vitro study. Eur. J. Dent. 2014, 8, 172-177. [CrossRef]

47. Tyagi, S.P.; Sinha, D.J.; Garg, P.; Singh, U.P.; Mishra, C.C.; Nagpal, R. Comparison of antimicrobial efficacy of propolis, Morinda citrifolia, Azadirachta indica (Neem) and 5\% sodium hypochlorite on Candida albicans biofilm formed on tooth substrate: An in-vitro study. J. Conserv. Dent. 2013, 16, 532-535.

48. Monawer, A.T. Role of Salvadora persica in eradication of Enterococcus faecalis isolated from infected dental pulp/in vitro study. Res. J. Pharm. Biol. Chem. Sci. 2018, 9, 1665-1670.

49. Ahmad, I.; Irfan, S.; Abohashrh, M.; Wahab, S.; Abullais, S.S.; Javali, M.A.; Nisar, N.; Alam, M.M.; Srivastava, S.; Saleem, M.; et al. Inhibitory Effect of Nepeta deflersiana on Climax Bacterial Community Isolated from the Oral Plaque of Patients with Periodontal Disease. Molecules 2021, 26, 202.

50. Al-Madi, E.M.; Almohaimede, A.A.; Al-Obaida, M.I.; Awaad, A.S. Comparison of the Antibacterial Efficacy of Commiphora molmol and Sodium Hypochlorite as Root Canal Irrigants against Enterococcus faecalis and Fusobacterium nucleatum. Evid. Based Complement. Alternat. Med. 2019, 2019, 6916795.

51. Rafiq, Z.; Narasimhan, S.; Haridoss, M.; Vennila, R.; Vaidyanathan, R. Punica granatum rind extract: Antibiotic potentiator and efflux pump inhibitor of multidrug resistant Klebsiella pneumoniae clinical isolates. Asian J. Pharm. Clin. Res. 2017, 10, 1-5. [CrossRef]

52. Cristo, J.S.; Matias, E.F.; Figueredo, F.G.; Santos, J.F.; Pereira, N.L.; Junior, J.G.; Aquino, P.E.; Nogueira, M.N.; Ribeiro-Filho, J.; Cunha, F.A.; et al. HPLC profile and antibiotic-modifying activity of Azadirachtaindica A. Juss (Meliaceae). Ind. Crop. Prod. 2016, 94, 903-908. [CrossRef] 
53. Jungermann, G.B.; Burns, K.; Nandakumar, R.; Tolba, M.; Venezia, R.A.; Fouad, A.F. Antibiotic resistance in primary and persistent endodontic infections. J. Endod. 2001, 37, 1337-1344. [CrossRef]

54. Skučait, N.; Pečiulien, V.; Manelien, R.; Mačiulskien, V. Antibiotic prescription for the treatment of endodontic pathology: A survey among Lithuanian dentists. Medicina 2010, 46, 806-813. [CrossRef]

55. Al-Ahmad, A.; Ameen, H.; Pelz, K.; Karygianni, L.; Wittmer, A.; Anderson, A.C.; Spitzmüller, B.; Hellwig, E. Antibiotic resistance and capacity for biofilm formation of different bacteria isolated from endodontic infections associated with root-filled teeth. $J$. Endod. 2014, 40, 223-230. [CrossRef] [PubMed]

56. MacNeill, S.; Rindler, E.; Walker, A.; Brown, A.R.; Cobb, C.M. Effects of tetracycline hydrochloride and chlorhexidine gluconate on Candida albicans. An in vitro study. J. Clin. Periodontol. 1997, 24, 753-760. [CrossRef] [PubMed] 